\title{
Onshore-offshore pattern and variability in distribution and abundance of bay anchovy Anchoa mitchilli eggs and larvae in Chesapeake Bay
}

\author{
J. M. MacGregor, E. D. Houde* \\ The University of Maryland System, Center for Environmental and Estuarine Studies, Chesapeake Biological Laboratory, \\ PO Box 38, Solomons, Maryland 20688-0038, USA
}

\begin{abstract}
The pattern and daily variability of kilometer scale, onshore-offshore distributions of bay anchovy Anchoa mitchilli eggs and larvae were determined from $4 \mathrm{~d}$ of repetitive sampling on a transect in mid-Chesapeake Bay. The $13 \mathrm{~km}$ transect ran from nearshore to the most offshore area of the Bay, passing through a river-plume front. Most spawning by bay anchovy occurred offshore. Eggs and recently hatched larvae were 30 to 200 times more abundant offshore than at inshore and frontal stations. Few eggs and larvae occurred below the pycnocline, where oxygen levels of ten were too low for survival or normal development. Mean larval lengths and relative (but not absolute) abundances of large ( $\geq 5.5 \mathrm{~mm}$ standard length) larvae increased in an offshore to inshore direction. Apparent larval mortality rates, which were both size- and area-specific, were highest offshore and higher for small length classes. There was no indication that anchovy eggs or larvae were concentrated in the frontal region, but gelatinous predators and zooplankton suitable as larval prey tended to increase at the front. While significant transport of larvae from offshore to inshore may occur, most larvae of all sizes were offshore, indicating that recruitment of anchovy is most dependent on processes in the offshore region.
\end{abstract}

KEY WORDS: Bay anchovy - Eggs - Larvae - Onshore-offshore distribution - Mortality rates · Chesapeake Bay

\section{INTRODUCTION}

The apparent abundances of bay anchovy Anchoa mitchilli year classes have varied more than 10 -fold during the past $30 \mathrm{yr}$ in Chesapeake Bay, USA (Horwitz 1987, Newberger \& Houde 1995). Daily spawning during summer produces cohorts of eggs and larvae in great abundance, which experience high and variable mortality (Dorsey 1993, Houde et al. 1994, Dorsey et al. 1996). Few anchovy live beyond age 1 (Newberger \& Houde 1995) and most annual production occurs in the larval stage (Wang \& Houde 1995), indicating that prerecruit dynamics drive year class fluctuations and variability in production.

-Addressee for correspondence. E-mail: ehoude@cbl.cees.edu
In a conceptual model, Dovel (1971) proposed that bay anchovy spawned primarily in the mesohaline, shoal regions of the estuarine Chesapeake Bay and that larvae subsequently were advected or migrated up-Bay and into low-salinity tributaries which served as juvenile nurseries. Recent research has demonstrated that spawning actually is widespread (Olney 1983, Dorsey 1993), is most intense offshore (Dalton 1987, MacGregor 1994), and depends upon individual females spawning repeatedly during an approximate 3 mo peak period (Luo \& Musick 1991, Zastrow et al. 1991). The pelagic eggs of bay anchovy develop rapidly and hatch in 20 to $24 \mathrm{~h}$. Some larvae, presumably by selective tidal transport, migrate into tributaries and are advected upstream (Loos \& Perry 1991). But, most larvae of all sizes occur offshore (MacGregor 1994). Trawl catches of juvenile recruits do indicate that a selective 
up-Bay translocation of larvae and juveniles does occur (Wang \& Houde 1995).

The Chesapeake Bay is a large estuary, $>250 \mathrm{~km}$ long and averaging $>15 \mathrm{~km}$ wide (Fig. 1). It can be partitioned into inshore (shoal), offshore (Bay channel), and frontal regions associated with the plumes of its many tributaries. Tidal and river-plume fronts are obvious features that, through convergent properties or eddies resulting from secondary currents, are hypothesized to promote plankton production, aggregate ichthyoplankton and gelatinous predators, and perhaps affect recruitment potential of bay anchovy (Pingree 1978, Seliger et al. 1981, Mackas et al. 1985. LeFevre 1986, Largier 1993). Frontal convergences are zones where fish larvae may accumulate or experience growth rates, mortality rates, and stage durations that differ significantly from non-frontal regions (Munk et al. 1986, Kiørboe et al. 1988, Govoni et al. 1989, Munk 1993, Kingsford \& Suthers 1994).

Our objectives were to define the onshoreoffshore distribution patterns of bay anchovy eggs and larvae on a transect that began nearshore, crossed a river-mouth front and extended offshore to the channel region of Chesapeake Bay. We examined the temporal (daily) and spatial variability in distributions and abundances of bay anchovy eggs and larvae, zooplankton, and gelatinous predators of eggs and larvae. We estimated and compared the apparent mortality rates of anchovy larvae in the offshore, frontal and inshore regions along the transect.

\section{METHODS}

Study area. Ichthyoplankton sampling was conducted at 8 stations on a transect extending offshore approximately $13 \mathrm{~km}$ from the mouth of the Patuxent River, Maryland (Fig. 1). Two inshore (1 and 2), 4 frontal ( 3 to 6 ) and 2 offshore ( 7 and 8 ) stations were designated. Stations in the frontal region were designated based upon drogue releases, bottom topography, and observations of temperature and salinity profiles (MacGregor 1994).

Sampling. Ichthyoplankton surveys were conducted on 4 dates in July 1988. Surveys were carried out on 2 ebb (12 and 13 July) and 2 flood (14 and 15 July) tide cycles during daylight hours. Depth profiles of temperature, salinity and oxygen at each station were obtained during the surveys from CTD casts and water samples pumped at specified depths.

A plume front off the mouth of the Patuxent River often was clearly visible. Foam lines and accumula-
Fig. 1 Chesapeake Bay (USA) and the sampling transect. The frontal region is indicated. Station numbers: 1 and 2, inshore region; 3 to 6. frontal region; 7 and 8 , of shore region tions of debris were common. The front is generated by river flow and tides. It is prevalent on the ebb and tends to dissipate on flooding tides. A sill at the mouth of the Patuxent River (Fig. 2) is a topographic feature believed to enhance the characteristics of the frontal feature (W. Boicourt pers. comm.). Frontal features are weakest during summer months when bay anchovy spawns

On 12,13 and 15 July, ichthyoplankton was collected in a $60 \mathrm{~cm}, 280 \mu \mathrm{m}$ mesh bongo net sampler with an opening-closing mechanism. On those dates, 2 pairs of 1 min oblique tows were made at each station. The first replicate pair was from near-bottom to the pycnocline and the second was from the pycnocline to surface. At stations with no obvious pycnocline, the water column was divided in half for each pair of oblique tows. The sampling plan differed on 14 July. On that day, a single bongo net tow of 1 min duration was made at each station from near-bottom to surface, with no division at the pycnocline. In addition, a 2 min oblique tow of a $2 \mathrm{~m}^{2}$ mouth, Tucker trawl with $700 \mu \mathrm{m}$ meshes was made from the pycnocline to surface to supplement numbers of larger ( $\geq 7.5 \mathrm{~mm}$ ) larvae.

Flowmeters in the mouths of both the bongo net and Tucker trawl allowed volumes filtered to be calculated from which densities (number $\mathrm{m}^{-3}$ ) and abundances (number under $1 \mathrm{~m}^{2}$ ) of eggs and larvae were estimated. Ichthyoplankton samples were fixed immediately in buffered $5 \%$ seawater formalin. 

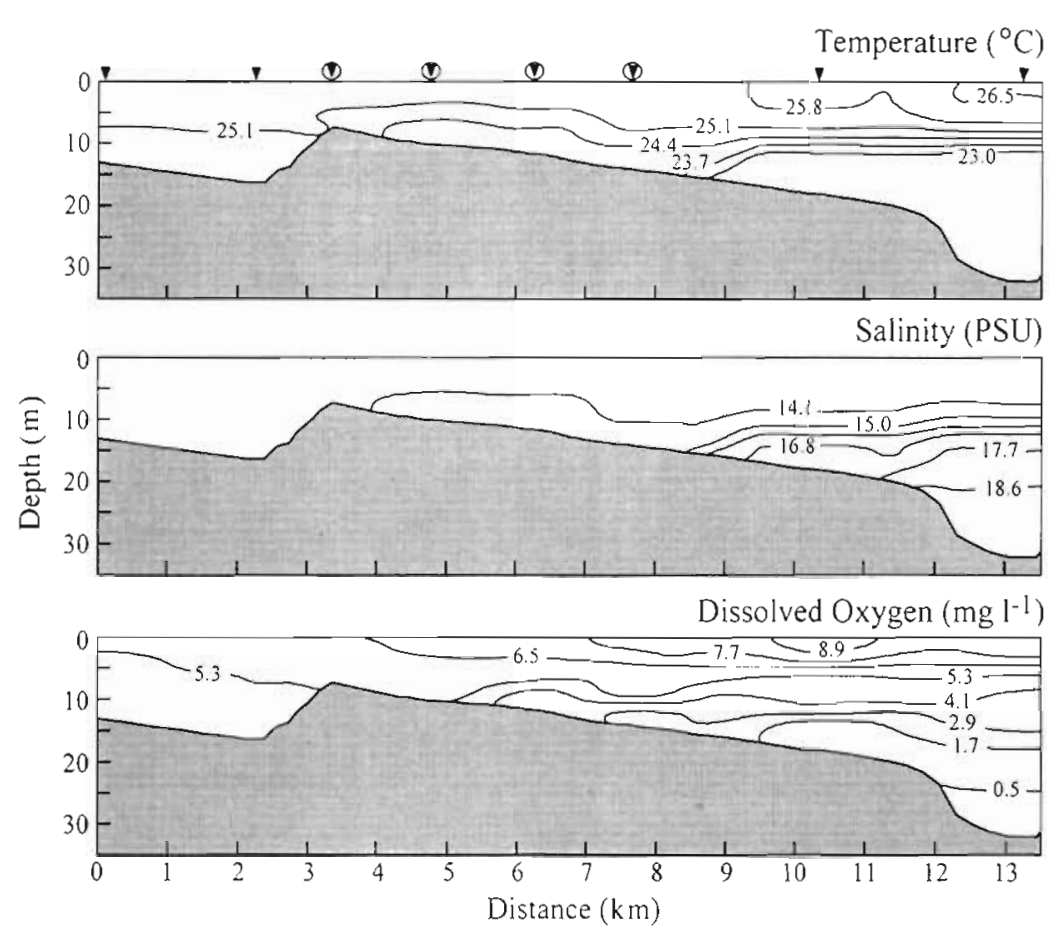

Fig. 2. Contour plots of mean temperature $\left({ }^{\circ} \mathrm{C}\right.$ ), salinity (PSU), and dissolved oxygen ( $\mathrm{mg} \mathrm{l}^{-1}$ ) along the sampling transect on $4 \mathrm{~d}, 12$ to $15 \mathrm{July}$ 1988. Markers $(\nabla)$ indicate station locations; (O) indicate frontal zone stations zooplankton samples were concentrated to a standard volume of $100 \mathrm{ml}$ and three $1 \mathrm{ml}$ aliquots were examined and counted to estimate densities (number $\mathrm{l}^{-1}$ ). Zooplankton organisms were identified and assigned to the following broad categories: copepods, copepodites, copepod nauplii, cirripede nauplii, polychaete larvae, and veliger larvae.

Data and analysis. Temperature, salinity and dissolved oxygen data were analyzed and contour-plotted using SURFER software (Golden Software). Ichthyoplankton numbers in samples were converted to mean abundances (number under $1.0 \mathrm{~m}^{2}$ ) and summarized by date, station, depth stratum (i.e. below or above pycnocline) and replicate.

Abundances of larvae $\leq 5.5 \mathrm{~mm} \mathrm{SL}$ were adjusted to correct for extrusion of some small larvae through the bongo net's $280 \mu \mathrm{m}$ meshes. The adjustment was based upon comparisons of 4 larval collections from paired 53 and $280 \mu \mathrm{m}$ mesh nets on the $60 \mathrm{~cm}$ bongo net sampler. We assumed that the $53 \mu \mathrm{m}$ meshes retained all larvae. Abundance
The 2 common species of gelatinous predator during the study period were the lobate ctenophore Mnemiopsis leidyi and the scyphomedusa Chrysara quinquecirrha. They are important consumers of zooplankton and ichthyoplankton, and are major predators on bay anchovy eggs and larvae (Cowan \& Houde 1993, Purcell et al. 1994). Total volumes of the combined gelatinous predators in each plankton net catch were measured to the nearest $1.0 \mathrm{ml}$ immediately after collection.

Pumped samples of zooplankton, including microzooplankton that are potential prey of anchovy larvae, were collected on 3 of the 4 sampling dates. Fifty liters of water were pumped (approx. $30 \mathrm{l} \mathrm{min}^{-1}$ ) from each of 3 discrete depths (near-bottom, pycnocline and surface) and concentrated on a $35 \mu \mathrm{m}$ filter. Each sample was preserved in buffered, $5 \%$ seawater formalin. Chlorophyll a (chl a) concentrations were determined at each depth by filtering 400 to $500 \mathrm{ml}$ of the pumped water onto glass fiber filters, which were frozen and brought to the laboratory for extraction and analysis.

In the laboratory, anchovy eggs, larvae and other ichthyoplankton were removed from samples under a binocular microscope. Subsamples of 100 anchovy larvae were randomly selected from each sample (or all larvae if there were fewer than 100) and standard lengths (SL) were measured to nominal $0.01 \mathrm{~mm}$ SL using JAVA (Imaging Technology, Inc.) software. The ratios, i.e. $53: 280 \mu \mathrm{m}$ catches of larvae in $1.0 \mathrm{~mm}$ length classes from 1.5 to $7.5 \mathrm{~mm}$, were regressed on standard length. A predictive equation was obtained:

$$
R=2.958-0.342 L, \mathrm{n}=6, \mathrm{r}^{2}=0.93
$$

where $R$ is the ratio $(53: 280 \mu \mathrm{m})$ of larval abundances and $L$ is standard length $(\mathrm{mm})$. The ratio was $>1.0$ for larvae $\leq 5.5 \mathrm{~mm}$ SL. Abundances of $\leq 5.5 \mathrm{~mm}$ SL larvae from $280 \mu \mathrm{m}$ mesh samples were multiplied by $R$ to correct for extrusion. Corrected abundances of the smallest length classes were nearly 2.5 times higher than uncorrected abundances.

Abundances or densities of organisms were logtransformed prior to statistical analyses to homogenize variances, thus satisfying requirements for analysis of variance (ANOVA). ANOVA was used to test for differences in mean $\log _{10}$ abundances among dates, stations, regions and depth strata. When ANOVA results were significant ( $p<0.05$ ), Tukey's multiple comparison test was applied to compare individual means.

The apparent, length-specific mortality rates $\left(Z_{1}\right)$ were estimated by regressing $\log _{e}$-transformed abundances (number under $100 \mathrm{~m}^{2}$ ) of anchovy larvae in $0.5 \mathrm{~mm}$ length classes on length. The slopes of the regression lines were estimates of $Z_{1}$. To truly estimate mortality, these estimates of relative losses presume that birth rates were constant and directional transport losses were minimal. A $0.5 \mathrm{~mm}$ length increase is approximately 
equivalent to $1 \mathrm{~d}$ growth in bay anchovy larvae (Houde \& Schekter 1981, Leak \& Houde 1987. Cowan \& Houde 1990, Castro \& Cowen 1991). Thus, $Z_{1}$ values $\left(\mathrm{mm}^{-1}\right)$ were converted $\left(\mathrm{mm}^{-1} \times \mathrm{mm} \mathrm{d}^{-1}\right)$ to approximate daily $\left(\mathrm{d}^{-1}\right)$ instantaneous mortalities $\left(Z_{\mathrm{d}}\right)$. Analysis of variance was used to test if mean loss rates $\left(Z_{1}\right)$ differed among dates, stations, regions or depth strata.

\section{RESULTS}

\section{Hydrography}

Hydrographic conditions were typical for midChesapeake Bay during July (Fig. 2). An oxycline and pycnocline generally coincided at approximately $10 \mathrm{~m}$ depth. Subpycnocline water often was hypoxic. In the offshore region, dissolved oxygen values at $>20 \mathrm{~m}$ depth usually were anoxic or nearly so $\left(\leq 0.5 \mathrm{mg} \mathrm{l}^{-1}\right)$. The frontal region, although poorly defined by hydrography during this season, represents a transition zone between inshore and offshore regions. Foam lines and slicks in the zone usually were visible, indicating probable convergence at the front.

\section{Egg and larvae abundances}

Eggs and larvae of bay anchovy were abundant during the $4 \mathrm{~d}$ period. Mean abundances were 1143.9 eggs $\mathrm{m}^{-2}$ and 194.5 larvae $\mathrm{m}^{-2}$, respectively (Table 1 ). Abundances differed among dates (ANOVA, p < 0.05). Lowest egg and larvae abundances were observed on 12 July $(p<0.05)$.

Mean abundances of eggs and larvae differed among the 8 transect stations (ANOVA, $p<0.0001$ )
Table 2. Bay anchovy egg and larvae abundances (number under $1.0 \mathrm{~m}^{2}$ ) in the offshore, frontal and inshore regions on the sampling transect illustrated in Fig. 1. Offshore: Stns 7 and 8; Frontal: Strns 3, 4, 5 and 6; Inshore: Stns 1 and 2 . Identical superscripts on mean values indicate no significant difference ( $p>0.05$, Tukey's comparison procedure)

\begin{tabular}{|c|c|c|c|}
\hline & Inshore & $\begin{array}{l}\text { Regions } \\
\text { Frontal }\end{array}$ & Offshore \\
\hline \multicolumn{4}{|l|}{ Eggs } \\
\hline Mean & $624.6^{\mathrm{b}}$ & $227.0^{r}$ & $3515.3^{d}$ \\
\hline SE & 182.8 & 76.1 & 1055.4 \\
\hline \multicolumn{4}{|l|}{ Larvae } \\
\hline Mean & $16.2^{b}$ & $33.9^{b}$ & $686.2^{4}$ \\
\hline SE & 2.3 & 14.7 & 207.6 \\
\hline
\end{tabular}

and among the 3 regions (ANOVA, p < 0.05). Abundances of eggs at offshore Stns 7 and 8 were an order of magnitude higher than those at inshore and frontal region stations (Tables 1 \& 2). Mean egg abundance in the frontal region was significantly lower $(p<0.05)$ than abundances in either the offshore or inshore regions (Table 2). Larval abundances also were highest offshore and varied by more than 2 orders of magnitude across the $13 \mathrm{~km}$ transect (Table 1). Mean larval abundance was significantly higher offshore than inshore or within the frontal region (Table 2).

Anchovy eggs and larvae were less abundant below the pycnocline than above it on each sampling day at all stations. The above-pycnocline mean egg abundance, $961.7 \mathrm{~m}^{-2}$, was 28 times higher (ANOVA, $\mathrm{p}<$ $0.005)$ than the below-pycnocline mean, $34.4 \mathrm{~m}^{-2}$. The above-pycnocline mean larval abundance, $167.2 \mathrm{~m}^{-2}$, was 36 times higher (ANOVA, p $<0.005$ ) than the below-pycnocline mean, $4.6 \mathrm{~m}^{-2}$.

At the inshore stations, a higher proportion of anchovy eggs and larvae occurred below the pycno-

Table 1. Bay anchovy egg and larvae mean abundances (number under $1.0 \mathrm{~m}^{2}$ ) on 4 dates and at 8 stations. Stations are indicated on Fig. 1. Identical superscripts on mean values indicate no significant difference ( $p>0.05$, Tukey's comparison procedure)

\begin{tabular}{|c|c|c|c|c|c|c|c|c|c|}
\hline \multicolumn{2}{|c|}{ Dates (July 1988): } & 12 & \multicolumn{2}{|c|}{13} & \multicolumn{2}{|c|}{14} & \multicolumn{2}{|c|}{15} & Grand mean \\
\hline \multicolumn{10}{|l|}{ Eggs } \\
\hline Mean & \multicolumn{2}{|r|}{$371.6^{b}$} & \multicolumn{2}{|c|}{$955.7^{\mathrm{d}}$} & \multicolumn{2}{|c|}{$1587.4^{\circ}$} & \multicolumn{2}{|c|}{$1660.9^{d}$} & 1143.9 \\
\hline SE & \multicolumn{2}{|r|}{25.0} & \multicolumn{2}{|c|}{74.0} & \multicolumn{2}{|c|}{747.5} & \multicolumn{2}{|c|}{248.3} & 302.2 \\
\hline \multicolumn{10}{|l|}{ Larvae } \\
\hline Mean & \multirow{2}{*}{\multicolumn{2}{|c|}{$\begin{array}{c}50.5^{b} \\
1.9\end{array}$}} & \multirow{2}{*}{\multicolumn{2}{|c|}{$\begin{array}{c}305.3^{\circ} \\
54.7\end{array}$}} & \multirow{2}{*}{\multicolumn{2}{|c|}{$\begin{array}{l}262.2^{a} \\
171.2\end{array}$}} & \multirow{2}{*}{\multicolumn{2}{|c|}{$\begin{array}{c}159.9^{\mathrm{a}} \\
16.0\end{array}$}} & 194.5 \\
\hline $\mathrm{SE}$ & & & & & & & & & 56.9 \\
\hline Stations: & 1 & 2 & 3 & 4 & 5 & 6 & 7 & 8 & Grand mean \\
\hline \multicolumn{10}{|l|}{ Eggs } \\
\hline Mean & $878.8^{\text {abc }}$ & $370.3^{\text {abcd }}$ & $215.7^{\text {bed }}$ & $113.7^{\mathrm{cd}}$ & $997^{\mathrm{d}}$ & $478.8^{\text {abed }}$ & $2310.6^{a b}$ & $4720.1^{d}$ & 1143.9 \\
\hline $\mathrm{SE}$ & 322.4 & 94.4 & 43.6 & 33.3 & 38.3 & 283.5 & 668.0 & 1945.1 & 302.2 \\
\hline \multicolumn{10}{|l|}{ Larvae } \\
\hline Mean & $14.4^{\mathrm{cd}}$ & $18.0^{\mathrm{cd}}$ & $4.9^{d}$ & $14.5^{\mathrm{d}}$ & $16.7^{\mathrm{cd}}$ & $99.3^{b c}$ & $358.9^{\mathrm{ab}}$ & $1013.5^{\mathrm{d}}$ & 194.5 \\
\hline $\mathrm{SE}$ & 3.0 & 3.6 & 1.5 & 5.1 & 7.2 & 48.1 & 94.8 & 347.4 & 113.7 \\
\hline
\end{tabular}


cline. Offshore, eggs and larvae were 79 and 89 times less abundant, respectively, below the pycnocline (where the water was hypoxic or anoxic) than above it. Inshore, where water was not hypoxic, egg and larval abundances were only 6 and 4 times less abundant, respectively, in below-pycnocline collections.

\section{Sizes of larvae}

Most bay anchovy larvae were recently hatched and $<3.0 \mathrm{~mm}$ SL. Standard lengths in the bongo net catches ranged from 1.04 to $12.34 \mathrm{~mm} \mathrm{SL}$ and the overall mean was $2.91 \mathrm{~mm}$ SL (Table 3). Mean lengths did not differ among dates (ANOVA, $p>0.10$ ). Mean length at offshore stations $(2.46 \mathrm{~mm} \mathrm{SL})$ was significantly less $(p<0.05)$ than mean length in the frontal and inshore regions $(3.00$ and $3.19 \mathrm{~mm} \mathrm{SL}$, respectively) (Table 3).

Mean larval length tended to increase in an offshore to inshore direction along the transect (Fig. 3). Larvae of longest mean lengths, 3.46 and $3.43 \mathrm{~mm} \mathrm{SL}$, were collected at Stns 2 and 5, respectively. In the offshore and frontal regions, mean lengths of larvae collected below the pycnocline were less than mean lengths above it. At the 2 inshore stations, mean lengths were longer below the pycnocline (Fig. 3A). A regression equation describes the decline in mean lengths of larvae from inshore to offshore (Fig. 3B), indicating a $0.06 \mathrm{~mm}$ decrease per $\mathrm{km}$. Most of the decline occurred at Stns 6,7 and 8 .

The length-frequency distributions of bay anchovy larvae were dominated by recently hatched larvae in the 2.0 to $2.5 \mathrm{~mm}$ SL class, but the distributions were multimodal at all stations on the 4 dates. At the offshore Stns 7 and 8 , newly hatched larvae $(\leq 2.5 \mathrm{~mm} \mathrm{SL})$ constituted $>98 \%$ of the larval catch, a reflection of the high offshore egg abundance (Table 2).

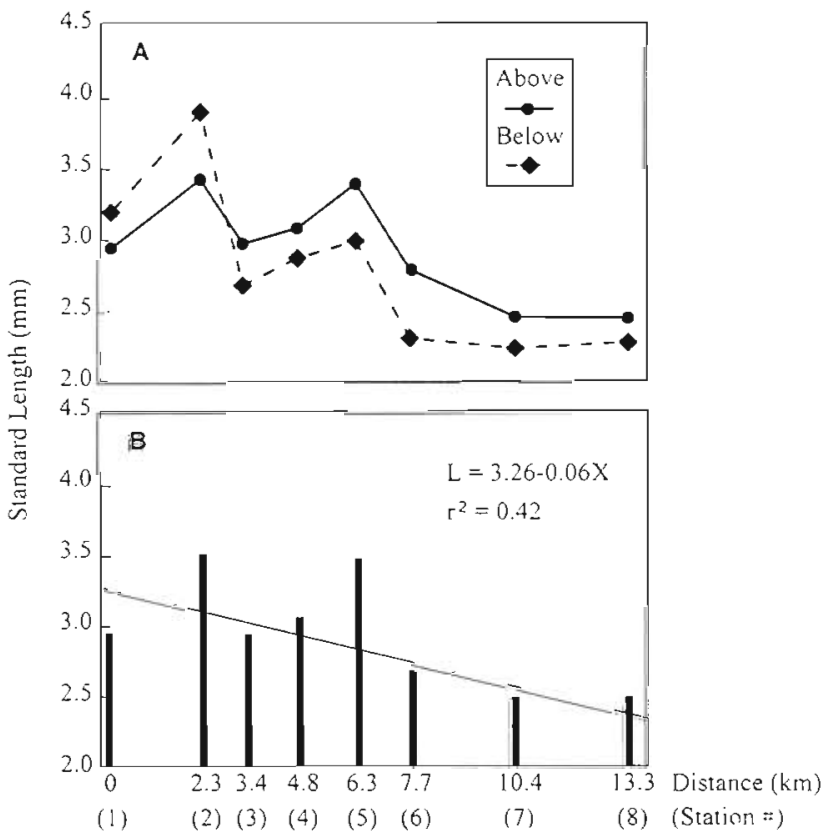

Fig. 3. Mean standard lengths ( $\mathrm{mm}$ ) of bay anchovy at each station during the 12 to 15 July 1988 period. (A) Mean lengths above and below the pycnocline. (B) Mean lengths for entire water column. The regression equation describes the decline in mean larval lengths in relation to distance offshore

\section{Size-specific abundances of larvae}

The absolute abundances of large anchovy larvae ( $\geq 5.5 \mathrm{~mm}$ SL) were highest offshore (Fig. 4). However, relative abundances of large larvae increased in the frontal and inshore regions (Fig. 5) and were significantly higher $(\mathrm{p}<0.05)$ inshore than offshore. The proportion of anchovy larvae categorized as large peaked at Stn 5, in the frontal zone (Fig. 5). The absolute abundances of large anchovy larvae ( $\geq 5.5 \mathrm{~mm} \mathrm{SL}$ ) always were significantly higher $(p<0.05)$ in the offshore

Table 3. Mean standard lengths ( $\mathrm{mm}$ ) of bay anchovy larvae on 4 dates and at 8 stations. Stations are indicated on Fig. 1. Identical superscripts on mean values indicate no significant difference $(p>0.05$, Tukey's comparison procedure)

\begin{tabular}{|c|c|c|c|c|c|c|c|c|c|}
\hline \multicolumn{2}{|c|}{ Dates (July 1988): } & 12 & \multicolumn{2}{|c|}{13} & \multicolumn{2}{|c|}{14} & \multicolumn{2}{|c|}{15} & Grand mean \\
\hline Mean & & $2.92^{\mathrm{a}}$ & \multicolumn{2}{|c|}{$2.70^{a}$} & \multicolumn{2}{|c|}{$3.03^{\mathrm{d}}$} & \multicolumn{2}{|c|}{$2.99^{\circ}$} & 2.91 \\
\hline $\mathrm{SE}$ & & 0.04 & & & & & & & 0.08 \\
\hline Stations: & 1 & 2 & 3 & 4 & 5 & 6 & 7 & 8 & Grand mean \\
\hline Mean & $2.91^{a b}$ & $3.46^{a}$ & $2.90^{\mathrm{ab}}$ & $3.02^{\mathrm{ab}}$ & $3.43^{\circ}$ & $2.65^{\mathrm{ab}}$ & $2.46^{\mathrm{b}}$ & $2.46^{b}$ & 2.91 \\
\hline SE & 0.12 & 0.09 & 0.21 & 0.10 & 0.33 & 0.09 & 0.10 & 0.21 & 0.08 \\
\hline Regions: & & Inshore & Front & & hore & & & & \\
\hline Mean & & $3.19^{\mathrm{a}}$ & 3.00 & & $6^{b}$ & & & & \\
\hline $\mathrm{SE}$ & & 0.13 & 0.12 & & & & & & \\
\hline
\end{tabular}




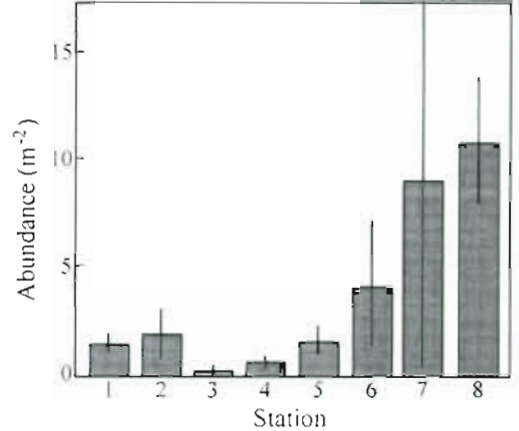

Fig. 4. Mean abundances of large bay anchovy $\left(\mathrm{m}^{-2}\right)$ from bongo net collections at 8 stations on a $13 \mathrm{~km}$ transect, 12 to 15 July 1988. Large larvae are $\geq 5.5 \mathrm{~mm} \mathrm{SL}$. Error bars are $\pm 2 \mathrm{SE}$

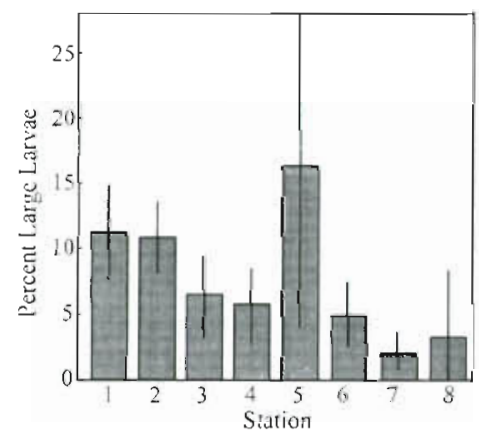

Fig. 5. Mean percentage of bay anchovy larvae in the bongo net collections that were large ( $\geq 5.5 \mathrm{~mm} \mathrm{SL}$ ) at each station during the 12 to 15 July 1988 period

region (Fig. 4) but were of lower and nearly equivalent abundances in the frontal and inshore regions

Additional evidence that abundance of large larvae was greater offshore than inshore or in the frontal region was obtained from the Tucker trawls on 14 July (Table 4). Larvae 7.5 to $14.0 \mathrm{~mm}$ SL were approximately twice as abundant offshore as in the other regions.
Table 4. Mean regional abundances and standard lengths of bay anchovy larvae in the 7.5 to $14.0 \mathrm{~mm}$ SL range, collected on 14 July 1988 in the $2.0 \mathrm{~m}^{2}$ Tucker trawl, $700 \mu \mathrm{m}$ meshes

\begin{tabular}{lccc|}
\hline & Inshore & $\begin{array}{c}\text { Regions } \\
\text { Frontal }\end{array}$ & Offshore \\
\hline Mean abundance $\left(\mathrm{m}^{-2}\right)$ & 1.2 & 0.9 & 2.2 \\
SE & 0.6 & 0.4 & 1.0 \\
Mean length $(\mathrm{mm})$ & 9.88 & 9.89 & 9.07 \\
SE & 0.28 & 0.36 & 0.53 \\
\hline
\end{tabular}

\section{Apparent mortality}

Mean apparent, length-specific mortality rates $\left(\mathrm{mm}^{-1}\right.$ ) on the 4 dates ranged from $Z_{1}=1.09$ to $Z_{1}=1.34$ (Table 5), which are equivalent to loss rates of 66.4 to $73.8 \% \mathrm{~mm}^{-1}$. At an assumed $0.5 \mathrm{~mm} \mathrm{~d}^{1}$ growth rate, the mean percent daily losses ranged from 42.0 to $48.8 \%$. The mean length-specific mortality rate over all dates and stations was $Z_{1}=1.24 \mathrm{~mm}^{-1}$, which is equivalent to a $71.1 \% \mathrm{~mm}^{-1}$ loss rate, or approximately $46.2 \% \mathrm{~d}^{-1}$.

Loss rates tended to decrease from offshore to inshore (Table 5). The apparent mortality rates thus were higher $(p<0.05)$ offshore than in the inshore and frontal regions (Table 5). Mean percentage losses were: offshore $85.0 \% \mathrm{~mm}^{-1}$; front $65.4 \% \mathrm{~mm}^{-1}$; inshore $60.5 \% \mathrm{~mm}^{-1}$.

The apparent, length-specific mortality rates declined as larvae increased in length. Mean loss rates in 3 designated standard-length classes, 2.5 to $4.5 \mathrm{~mm}$ (bongo net), 5.0 to $8.5 \mathrm{~mm}$ (bongo net), and 8.5 to $14.0 \mathrm{~mm}$ (Tucker trawl), differed significantly $(\mathrm{p}<0.05)$ (Fig. 6). Larvae in the 2.5 to $4.5 \mathrm{~mm}$ length class experienced a mean loss rate of $Z_{1}=1.52 \mathrm{~mm}^{-1}(78.1 \%$

Table 5. Length-specific, apparent mortality rates ( $\mathrm{mm}^{-1}$ ) of bay anchovy larvae collected in $60 \mathrm{~cm}$ bongo nets on 4 dates and at 8 stations. Stations are indicated on Fig. 1 Identical superscripts on mean values indicate no significant difference $(p>0.05$. Tukey's comparison procedure)

\begin{tabular}{|c|c|c|c|c|c|c|c|c|c|}
\hline \multicolumn{2}{|c|}{ Dates (July 1988): } & 12 & \multicolumn{2}{|c|}{13} & \multicolumn{2}{|c|}{14} & \multicolumn{2}{|c|}{15} & Grand mean \\
\hline Mean & & \multirow{2}{*}{$\begin{array}{l}1.09^{b} \\
0.03\end{array}$} & \multicolumn{2}{|c|}{$1.34^{a}$} & \multicolumn{2}{|c|}{$1.28^{\mathrm{ab}}$} & \multicolumn{2}{|c|}{$1.24^{\mathrm{b}}$} & 1.24 \\
\hline $\mathrm{SE}$ & & & & & & & & & 0.06 \\
\hline Stations: & 1 & 2 & 3 & 4 & 5 & 6 & 7 & 8 & Grand mean \\
\hline Mean & $0.83^{c}$ & $1.02^{b c}$ & $0.85^{\varsigma}$ & $1.21^{\mathrm{abc}}$ & $0.88^{\circ}$ & $1.30^{\mathrm{abc}}$ & $1.82^{\mathrm{ab}}$ & $1.98^{\circ}$ & 1.24 \\
\hline $\mathrm{SE}$ & 0.05 & 0.07 & 0.09 & 0.12 & 0.22 & 0.21 & 0.11 & 0.23 & 0.06 \\
\hline Regions: & & Inshore & Fron & & lore & & & & \\
\hline Mean & & $0.93^{b}$ & 1.0 & & & & & & \\
\hline SE & & 0.06 & 0.0 & & & & & & \\
\hline
\end{tabular}




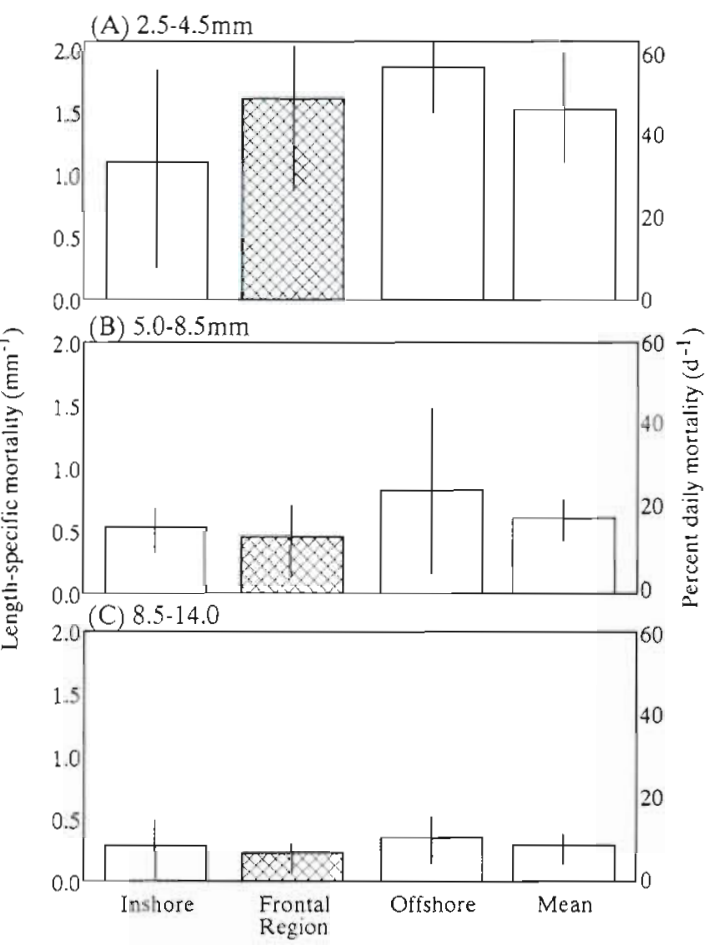

Fig. 6. Mean length-specific mortality rates $\left(\mathrm{mm}^{-1}\right)$ of bay anchovy larvae from inshore, frontal and offshore regions of Chesapeake Bay. Mortality rates for (A) 2.5 to $4.5 \mathrm{~mm} \mathrm{SL}$ larvae; (B) 5.0 to $8.5 \mathrm{~mm}$ SL larvae, and (C) Tucker trawl collected 8.5 to $14.0 \mathrm{~mm}$ SL larvae. Percent daily mortality is estimated based upon an assumed $0.5 \mathrm{~mm} \mathrm{~d}^{-1}$ growth rate

$\mathrm{mm}^{-1}$ ). The mean rate had declined to $0.60 \mathrm{~mm}^{-1}$ $\left(45.1 \% \mathrm{~mm}^{-1}\right)$ for 5.0 to $8.5 \mathrm{~mm}$ larvae and to $0.29 \mathrm{~mm}^{-1}$ $\left(25.2 \% \mathrm{~mm}^{-1}\right)$ for 8.5 to $14.0 \mathrm{~mm}$ larvae (Fig. 6). The apparent mortality rates for each of those length classes were higher offshore than in the frontal or inshore regions. Regional differences in $Z_{1}$ were pronounced for the 2.5 to $4.5 \mathrm{~mm}$ larvae but were minor for 8.5 to $14.0 \mathrm{~mm}$ larvae.

\section{Gelatinous predators}

Two major gelatinous predators of bay anchovy eggs and larvae in the net collections were the scyphomedusa Chrysara quinquecirrha and the lobate ctenophore Mnemiopsis leidyi. Their combined biovolumes did not differ significantly among dates or among stations (ANOVA, $\mathrm{p}>0.10$ ). Mean biovolume during the 4 dates was $148.2 \mathrm{ml} \mathrm{m}^{-2}$. On a regional basis, biovolumes of gelatinous zooplankton tended to be highest (although not significant at $\mathrm{p}=0.05$ ) in the frontal zone. Biovolumes were nearly 5 times higher (ANOVA, $\mathrm{p}<0.0001)$ above the pycnocline $\left(106.3 \mathrm{ml} \mathrm{m}^{-2}\right)$ than below it $\left(23.1 \mathrm{ml} \mathrm{m}^{-2}\right)$.

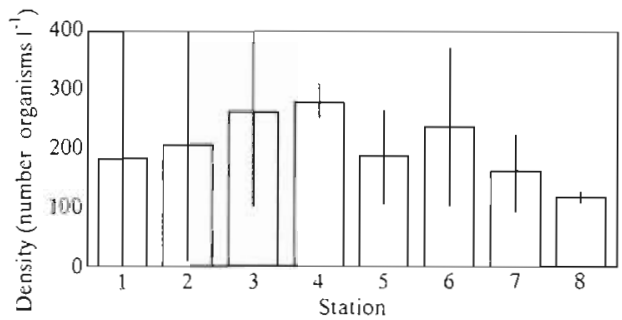

Fig. 7. Zooplankton mean densities (number organisms $\mathrm{l}^{-1}$ ) at 8 stations on a $13 \mathrm{~km}$ transect sampled during $3 \mathrm{~d}$ in July 1988. Stations are indicated on Fig. 1 Stns 3 to 6 were in the frontal region. Error bars are $\pm 2 \mathrm{SE}$. Taxa included in the analysis are listed in 'Methods'

\section{Zooplankton densities}

The mean density of zooplankton organisms in our analysis was $203.8 \mathrm{I}^{-1}$. Copepod nauplii were the most abundant (ANOVA, $p<0.0001$ ) organism $\left(163.1 \mathrm{l}^{-1}\right.$ ). There were no significant differences in mean combined-taxa zooplankton densities among stations, although the highest observed values were at stations in the frontal zone (Fig. 7). Regionally, densities tended to be higher, although not significantly so, in the frontal region compared to offshore and inshore. The mean density of zooplankton near surface $\left(346.5 \mathrm{l}^{-1}\right.$ ) was significantly higher $(p<0.05)$ than mean densities at the pycnocline and near bottom (169.0 and $102.5 \mathrm{l}^{-1}$, respectively).

\section{Chlorophyll a}

Mean chl a levels did not differ significantly during the sampling period. The overall mean level was $10.2 \mu \mathrm{g} \mathrm{l}^{-1}$. Mean chlorophyll a level, averaged over the entire water column, was significantly higher ( $\mathrm{p}<$ 0.05 ) in the frontal region than offshore and tended to be higher in the front than inshore.

\section{DISCUSSION}

In Chesapeake Bay, there are strong gradients in abundances of bay anchovy eggs and larvae, and in apparent mortality rates of larvae. Abundances and apparent mortality rates were consistently higher offshore during the $4 \mathrm{~d}$ study along a $13 \mathrm{~km}$ cross-bay transect. The role, if any, of the ephemeral tidal front near the mouth of the Patuxent River, with respect to anchovy reproduction and early life dynamics, remains unclear. Plankton densities and gelatinous predator biovolumes may, on average, be elevated in the front 

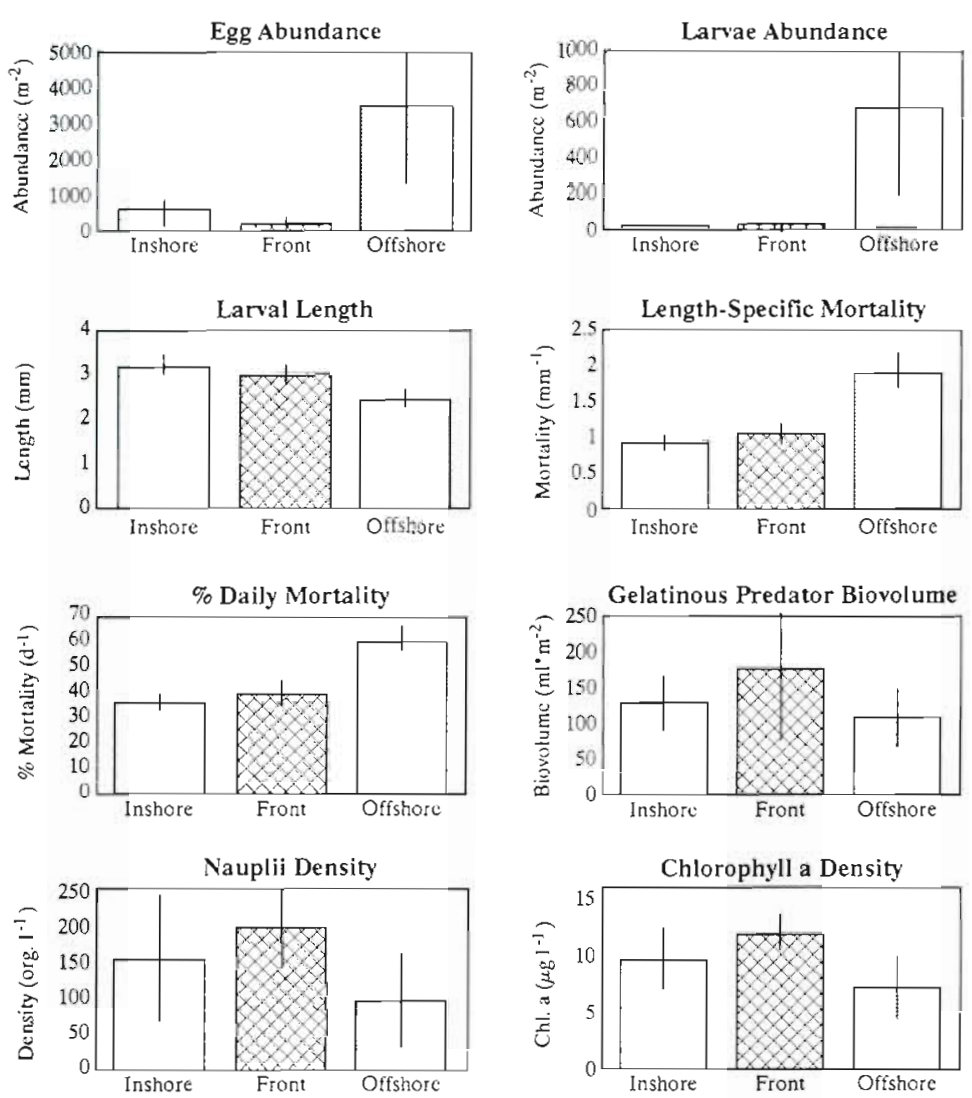

Fig. 8. Summary of mean values for each variable in the inshore, frontal and offshore regions on a $13 \mathrm{~km}$ transect in Chesapeake Bay. Stations and regions are described in 'Methods'

relative to inshore or offshore regions (Fig. 8). Yet, anchovy egg abundances were lowest in the frontal region and larval abundances also were very low at the front compared to the offshore zone. What is clear is that most spawning by bay anchovy occurs offshore, explaining the egg abundance and distribution results, and partly explaining observed larval distributions and loss rates.

The high abundances of bay anchovy eggs and recently hatched larvae demonstrated that the offshore region is the primary spawning region in Chesapeake Bay. Because incubation time for bay anchovy eggs is $<24 \mathrm{~h}$, dispersal or transport do not account for the observed egg distributions. Egg abundances offshore are the result of intensive spawning there, not resultant transport from other regions.

In this study, chl a concentration and densities of zooplankton suitable as anchovy larval prey were equal to or lower offshore than those found in the frontal or inshore regions (Fig. 8). Consequently, no apparent nutritional advantage to larvae results from. eggs being spawned offshore. In fact, if there were a nutritional advantage, it potentially was in the frontal region where densities of copepod nauplii, an important food of bay anchovy larvae (Houde \& Alpern-Lovdal 1984), averaged $200 \mathrm{I}^{-1}$ on the dates of these surveys. This mean density was nearly twice that observed offshore (Fig. 8) As in other described river plumes (e.g. Mackas \& Luottit 1988, Dagg \& Whitledge 1991, Grimes \& Finucane 1991, St. John \& Pond 1992), chl a and zooplankton densities were higher in the frontal region. But, in our study, the abundances of bay anchovy eggs and larvac were low within and near the front.

Jellyfish can be effective predators on fish eggs and larvae (Bailey 1984, Purcell 1985. 1989). Experimental research has demonstrated that increases in gelatinous predator biovolumes result in increased larval mortality (e.g. de Lafontaine \& Leggett 1988, Cowan \& Houde 1993). On average, gelatinous predator biovolumes were about 1.5 times higher in the Patuxent River frontal region than in the inshore and offshore regions of Chesapeake Bay (Fig. 8). If the higher gelatinous predator biovolumes in the front were due primarily to the highly predaceous scyphomedusa Chrysaora quinquecirrha, rather than to the ctenophore Mnemiopsis leidyi, it potentially could have been a significant factor leading to increased egg and larval mortality (Cowan \& Houde 1993, Purcell et al. 1994) in the front.

Diel behavior of adult anchovy provides the probable explanation for low egg abundances in the frontal region. Fisheries acoustics and trawling studies in Chesapeake Bay have demonstrated that most adult bay anchovy move inshore during the day and offshore at night (Brandt et al, 1992). Spawning occurs at night (Zastrow et al. 1991). In addition, recent evidence suggests that adult bay anchovy may avoid spawning in areas of high gelatinous predator abundance (Dorsey et al. 1996), a behavior which might have reduced egg production in the frontal region.

Subpycnocline water in the offshore region, which was hypoxic or anoxic, contained few anchovy eggs and larvae. Mean abundances of anchovy eggs and larvae were nearly 2 orders of magnitude higher above the pycnocline than below it. Inshore, where hypoxia was absent or less severe below the pycnocline, anchovy egg and larval abundances still were 6 and 4 times higher, respectively, above the pycnocline. Anchovy eggs and larvae collected below the pycnocline often were in obviously poor condition. It appeared that many were dead before they were collected. Laboratory research has demonstrated that 
bay anchovy eggs can tolerate dissolved oxygen levels as low as $2.0 \mathrm{mg} \mathrm{l}^{-1}$ and bay anchovy yolk-sac larvae may tolerate levels as low as $1.5 \mathrm{mg} \mathrm{l}^{-1}$ (Houde \& Zastrow 1991). Offshore, dissolved oxygen levels below the pycnocline generally were $<2.0 \mathrm{mg} \mathrm{l}^{-1}$ during this study, which suggests that many eggs and newly hatched larvae below the pycnocline were dead or not viable when collected.

\section{Larval size distribution, apparent mortality and transport mechanisms}

The observed increase in mean larval length and in relative abundance of large anchovy larvae in an offshore to inshore direction suggested that anchovy larvae might have been advected shoreward or that size-specific mortality rates differed among regions. The mean and modal lengths offshore were $<2.5 \mathrm{~mm}$ SL, a length only slightly longer than the approximate $2.0 \mathrm{~mm}$ SL-at-hatch. It is possible that a net shoreward transport of larvae from the offshore region could have accounted in part for the $0.73 \mathrm{~mm}$ increase in mean larval length between the offshore and inshore regions.

Norcross \& Shaw (1984), Kingsford \& Choat (1986), Nakata (1989), and Murdoch et al. (1990) reported similar onshore-offshore trends in mean larval lengths and large larvae abundances. They attributed these trends to shoreward advection of recently hatched larvae by currents and tides. In the tidal Patuxent River, Loos \& Perry (1991) demonstrated that larval lengths and densities of large bay anchovy larvae increased from the river mouth to the upriver region, indicating that either upstream transport or differential mortality between the upstream and downstream regions could explain the results. They favored a transport hypothesis because differential mortality did not reasonably explain how numbers of large larvae, averaged over the spawning season, exceeded numbers of smaller larvae in the upriver region.

In our study, anchovy larvae of longest mean lengths came from samples collected below the pycnocline at the inshore Stns 1 and 2 in the mouth of the Patuxent River These larvae could have represented large individuals that potentially were susceptible to upstream advection in a 2-layered estuarine circulation (Weinstein et al. 1980, Miller et al. 1984, Laprise \& Dodson 1989).

A simulation transport model, which was developed and applied to data from the 3 regions of the Bay, suggested that offshore to inshore transport, if it occurred, was unlikely to have been an important factor affecting the distribution and abundance of bay anchovy larvae along the transect (MacGregor 1994). Under some circumstances, i.e extremely high or low larval mor- tality rates, the model demonstrated that transport losses and gains among regions could be important as a factor shaping the observed distributions. But, in general it appears that larval mortality was the primary cause of loss in each of the regions.

The differences among regions in mean larval lengths and relative abundances of large larvae probably were primarily a consequence of different mortality rates. The mean apparent mortality rate offshore was nearly double the rates in the inshore and frontal regions. It also is apparent that mortality rates differed among length classes of larvae. If mortality is sizeselective or density-dependent, the high abundance offshore of recently hatched larvae may have strongly influenced the mortality rate in that region. Comparing the length-specific mortality rates among regions for larvae in 3 length classes (Fig. 6), it was apparent that rates were higher offshore than inshore or in the frontal region. This suggests that mortality was not only size-selective but that it also differed between regions only a few kilometers apart. For the small $(2.5$ to $4.5 \mathrm{~mm} \mathrm{SL}$ ) and intermediate size (5.0 to $8.5 \mathrm{~mm} \mathrm{SL}$ ) larvae, apparent mortality offshore was significantly higher than mortality in the front or inshore. But, for the 8.5 to $14.0 \mathrm{~mm}$ SL larvae, the estimated offshore loss rate was similar to that in the other regions.

It is possible that processes leading to regional increases in mean larval length and relative abundance of large larvae inshore may be significant to recruitment of bay anchovy in Chesapeake Bay. But, the volume of the offshore region, where most eggs and larvae occurred, exceeded the volumes of the inshore and frontal regions by a factor of approximately 2.5 in each case, and the standing stock of anchovy larvae of all sizes was higher offshore. If a fraction of the bay anchovy larval population were advected shoreward from the offshore region, and if the inshore population suffered lower mortality rates throughout the larval period, such processes could influence the overall recruitment pattern in Chesapeake Bay. Based upon the present analysis, most recruits are likely to originate from spawning and larval production offshore. The inshore and frontal regions, though only a few kilometers distant from the offshore region, may contribute relatively little to baywide recruitment of bay anchovy. The generality of this tentative conclusion and its applicability to estuaries other than Chesapeake Bay require well designed research to elucidate the scale and pattern of processes that affect abundances and which ultimately control recruitment.

Acknowledgements. This is Contribution Number 2761 of the University of Maryland Center for Environmental and Estuarine Studies 


\section{LITERATURE CITED}

Bailey KM (1984) Comparison of laboratory rates of predation on five species of marine fish larvae by three planktonic invertebrates: effects of larval size on vulnerability. Mar Biol 79:303-309

Brandt SB, Mason DM, Patrick EV (1992) Spatially explicit models of fish growth rate. Fisheries 17:23-35

Castro LR, Cowen RK (1991) Environmental factors affecting the early life history of bay anchovy Anchoa mitchilli in Great South Bay, New York. Mar Ecol Prog Ser 76 : $235-247$

Cowan JH Jr, Houde ED (1990) Growth and survival of bay anchovy (Anchoa mitchilli) larvae in mesocosm enclosures. Mar Ecol Prog Ser 68:47-57

Cowan JH Jr, Houde ED (1993) Relative predation potentials of scyphomedusae, ctenophores and planktivorous fish on ichthyoplankton in Chesapeake Bay. Mar Ecol Prog Ser 95:55-65

Dagg MJ, Whitledge TE (1991) Concentrations of copepod nauplii associated with the nutrient-rich plume of the Mississippi River. Cont Shelf Res 11:1409-1423

Dalton PD (1987) Ecology of the bay anchory (Anchoa mitchilli) eggs and larvae in the mid-Chesapeake Bay. Masters thesis, University of Maryland, College Park, p 104

de Lafontaine Y, Leggett WC (1988) Predation by jellyfish on larval fish: an experimental evaluation employing in situ enclosures. Can J Fish Aquat Sci 45:1173-1190

Dorsey SE (1993) Daily variability in mortality of bay anchovy (Anchoa mitchilli) eggs and yolk-sac larvae in Chesapeake Bay, USA. Masters thesis, Unjversity of Maryland, College Park, p 1.09

Dorsey SE, Houde ED, Gamble JC (1996) Abundance and daily variability in mortality of bay anchovy. Anchoa mitchilli, eggs and yolk-sac larvae in Chesapeake Bay, USA. Fish Bull US 94:257-267

Dovel WL (1971) Fish eggs and larvae of the upper Chesapeake Bay. Natural Resource Institute, University of Maryland, Chesapeake Biological Laboratory, Special Report No. $4, \mathrm{p} 71$

Govoni JJ, Hoss DE, Colby DR (1989) The spatial distribution of larval fishes about the Mississippi River plume. Limnol Oceanogr 34:178-187

Grimes CB, Finucane JH (1991) Spatıal distribution and abundance of larval and juvenile fish, chlorophyll and macrozooplankton around the Mississippi River discharge plume, and the role of the plume in fish recruitment. Mar Ecol Prog Ser 75:109-119

Horwitz RJ (1987) Fish. In: Heck KL (ed) Ecological studies in the middle reach of Chesapeake Bay. Lecture notes on coastal and estuarine studies, Vol 23. Springer-Verlag, New York, p 167-224

Houde ED, Alpern-Lovdal J (1984) Seasonality of occurrence, foods and food preferences of ichthyoplankton in Biscayne Bay, Florida. Estuar Coast Shelf Sci 18:403-419

Houde ED, Gamble JC, Dorsey SE, Cowan JH Jr (1994) Mesocosms: the influence of gelatinous zooplankton on mortality of bay anchovy Anchoa mitchilli eggs and yolk-sac larvae. ICES J Mar Sci 51:383-394

Houde ED, Schekter RC (1981) Growth rates, rations and cohort consumption of marine fish larvae in relation to prey concentration. Rapp PV Réun Cons Int Explor Mer 178:441-453

Houde ED. Zastrow CE (1991) Bay anchovy. In: Funderburk SL, Mihursky JA, Jordan SJ, Riley D (eds) Habitat requirements for Chesapeake Bay living resources, 2nd edn. Liv-
Ing Resources Subcommittee, Chesapeake Bay Program, Annapolis, MD, p 8-1 to 8-14

Kingsford MJ, Choat JH (1986) Influence of surface slicks on the distribution and onshore movements of small fish. Mar Biol 91:161-171

Kingsford MJ, Suthers IM (1994) Dynamic estuarine plumes and fronts: importance to small fish and plankton in coastal waters of NSW, Australia. Cont Shelf Res 14: $655-672$

Kiørboe T, Munk P, Richardson K, Christensen V, Paulsen H (1988) Plankton dynamics and larval herring growth, drift and survival in a frontal area. Mar Ecol Prog Ser 44: 205-219

Laprise R, Dodson JJ (1989) Ontogenetic changes in the longitudinal distribution of two species of larval fish in a turbid well-mixed estuary. J Fish Biol 35 (Suppl A):39-47

Largier JL (1993) Estuarine fronts: how important are they? Estuaries 16:1-11

Leak JC, Houde ED (1987) Cohort growth and survival of bay anchovy Anchoa mitchilli larvae in Biscayne Bay, Florida. Mar Ecol Prog Ser 37:109-122

LeFevre J (1986) Aspects of the biology of frontal systems. Adv Mar Biol 23:163-299

Loos JJ, Perry ES (1991) Larval migration and mortality rates of bay anchovy in the Patuxent River. Thirteenth Annual Larval Fish Conference, Merida, Mexico. NOAA/NMFS Technical Report Series 95, p 65-76

Luo J, Musick JA (1991) Reproductive biology of the bay anchovy, Anchoa mitchilli, in Chesapeake Bay. Trans Am Fish Soc 120:701-710

MacGregor JM (1994) Onshore-offshore pattern and variability in distribution and abundance of bay anchovy. Anchoa mitchilli, in Chesapeake Bay. Masters thesis, University of Maryland, College Park, p 136

Mackas DL, Denman KL, Abbott MR (1985) Plankton patchiness: biology in the physical vernacular. Bull Mar Sci 37 : 652-674

Mackas DL, Louttit GC (1988) Aggregation of the copepod Neocalanus plumchrus at the margin of the Fraser River plume in the Strait of Georgia. Bull Mar Sci 43:810-824

Miller JM, Reed JP, Pietrafesa LJ (1984) Patterns, mechanisms and approaches to the study of migration of estuarinedependent fish larvae and juveniles. In: McCleave JD, Arnold GP, Dodson JJ, Neill WH (eds) Mechanisms of migration in fishes. Plenum Press, New York, p 209-225

Munk P (1993) Differential growth of larval sprat Sprattus sprattus across a tidal front in the eastern North Sea. Mar Ecol Prog Ser 99:17-27

Munk P. Christensen V, Paulsen J (1986) Studies of a larval herring (Clupea harengus L.) patch in the Buchan area. II. Growth, mortality and drift of Jarvae. Dana 6:11-24

Murdoch RC, Guo R, McCrone A (1990) Distribution of hoki (Macruronus novaezelandiae) eggs and larvae in relation to hydrography in eastern Cook Strait, September 1987 NZ J Mar Freshwater Res 24:529-539

Nakata H (1989) Transport and distribution of fish eggs and larvae in the vicinity of coastal fronts. Rapp PV Réun Cons Int Explor Mer 191:153-159

Newberger TA, Houde ED (1995) Population biology of bay anchovy (Anchoa mitchilli) in the mid-Chesapeake Bay. Mar Ecol Prog Ser 116:25-37

Norcross BL, Shaw RF (1984) Oceanic and estuarine transport of fish eggs and larvae: a review. Trans Am Fish Soc 133:153-165

Olney JE (1983) Eggs and early larvae of the bay anchovy, Anchoa mitchilli, and the weakfish, Cynoscion regalis, in lower Chesapeake Bay with notes on associated 
ichthyoplankton. Estuaries 6:20-35

Pingree RD (1978) Mixing and stabilization of phytoplankton distributions on the northwest European continental shelf. In: Steele JH (ed) Spatial patterns in plankton communities. NATO Conference Series IV, Marine Science Vol 3. Plenum Press, New York, p 181-200

Purcell JE (1985) Predation on fish eggs and larvae by pelagic cnidarians and ctenophores. Bull Mar Sci 37:739-755

Purcell JE (1989) Predation on fish larvae and eggs by the hydromedusa Aequoria victoria at a herring spawning ground in British Columbia. Can J Fish Aquat Sci 46: 1415-1427

Purcell JE, Nemazie DA, Dorsey SE, Houde ED, Gamble JC (1994) Predation mortality of bay anchovy (Anchoa mitchilli) eggs and larvae due to scyphomedusae and ctenophores in Chesapeake Bay. Mar Ecol Prog Ser 114: $47-58$

This article was presented by J. E. Purcell (Senior Editorial Advisor), Cambridge, Maryland, USA
Seliger HH, McKinley KR, Biggley WH, Rivkin RB, Aspden $\mathrm{KRH}$ (1981) Phytoplankton patchiness and frontal regions. Mar Biol 61:119-131

St John MA, Pond S (1992) Tidal plume generation around a promontory: effects on nutrient concentrations and primary productivity. Cont Shelf Res 12:339-354

Wang SB, Houde ED (1995) Distribution, relative abundance, biomass and production of bay anchovy Anchoa mitchilli in the Chesapeake Bay. Mar Ecol Prog Ser 121:27-38

Weinstein MP, Weiss SL, Hodson RG, Gerry LR (1980) Retention of three taxa of postlarval fishes in an intensively flushed tidal estuary, Cape Fear River, North Carolina. Fish Bull US 78:419-436

Zastrow CE, Houde ED, Morin LG (1991) Spawning, fecundity, hatch-date frequency and young-of-the-year growth of bay anchovy Anchoa mitchilli in mid-Chesapeake Bay. Mar Ecol Prog Ser 73:161-171

Manuscript first received: August 28, 1995

Revised version accepted: March 15, 1996 